\title{
A STÁTUSZKEZELÉS JÖVÖBELI ALKALMAZÁSÁT BEFOLYÁSOLÓ TÉNYEZŐK FELTÁRÁSA
}

\author{
PÁLFI DORINA \\ Eszterházy Károly Egyetem \\ Neveléstudományi Doktori Iskola
}

A státuszkezelés olyan pedagógiai eljárás, amely az osztálytermi méltányosság megteremtése miatt jelentős, következésképpen az esélyegyenlőtlenségek csökkentésének lehetőségét rejti magában. A státuszkezelés ismereteinek hatékonyabb elsajátítása szempontjából kulcsfontosságú, hogy megvizsgáljuk, melyek azok a tényezők, amelyek megerősítésével a pedagógusok fejlesztése eredményesebbé válik, és a státuszkezelés beépülhet az osztálytermi tevékenységükbe (K. Nagy és Révész, 2019). Kutatásunkban a státuszkezelés megismertetését végző képzők felmérése történik. Online kérdőívet használunk, amely nyitott kérdéseket tartalmaz a pedagógusok fejlesztésének nehézségeivel kapcsolatban. A válaszok tartalomelemzésén keresztül a pedagógusok döntését befolyásoló tényezőket tárjuk fel azzal a céllal, hogy amennyiben ezen tényezőket ismerjük, és ezekre képesek vagyunk hatni, úgy a státuszkezelés eredményesebben öröklődhet tovább a pedagógusok tevékenységébe.

\section{Bevezetés}

Ma Magyarországon a közoktatásban erős szegregáció figyelhető meg, ami azt jelenti, hogy szociális helyzetből fakadó különbségek alapján elkülönítenek bizonyos tanulócsoportokat, amelyek ezáltal hátrányokat élnek meg (Nahalka, 2017). Ez az egyén számára éppúgy negatív jelenség, mint az ország egészére nézve. Igazságtalan az a helyzet, hogy a szegényebb családok gyermekeinek az iskola nem biztosítja a társadalmi mobilitás lehetőségét, kudarcokat, hátrányokat kell megélniük származásuk miatt. Emellett az ország - azáltal, hogy az iskolák nem karolják fel, sőt ignorálják a hátrányos helyzetű családok gyerekeinek készségeit, képességeit - sok tehetséget veszít el, akik felnőttként hozzájárulhatnának az ország fejlődéséhez (Nahalka, 2016).

Azáltal, hogy az intézmények szelektálnak, elkülönítik a szociálisan hátrányos helyzetű gyerekeket a felsőbb társadalmi osztályok gyermekeitől, maguk generálják a problémát. Azok az iskolák, ahol együtt tanulnak és nevelődnek a gyerekek, ott is sok esetben éppúgy jelen van a szelekció azáltal, hogy két (vagy több) tanulócsoportot hoznak létre, külön osztályba sorolják a „problémás” tanulókat (K. Nagy, 2016). 
Az esélyegyenlőtlenségek kialakulásának megértéséhez a tudományos kutatások három értelmezési modellt kínálnak, amelyeket elsősorban Nahalka István (2016) tanulmányának felhasználásával mutatok be. Az első értelmezési modell a deficitmodell, amely a leginkább jellemző a magyar pedagógiai felfogásra. Ez az elmélet azt mondja, hogy azért alakulnak ki egyenlőtlenségek, mert a gyerekek a közoktatásba eleve hátrányokkal érkeznek. Kevesebb a hozott tudásuk, rosszabb kommunikációs készségekkel, negatív viselkedési formákkal, az iskola számára nem megfelelő normákkal rendelkeznek. Ezek a deficitek elvezetnek a rosszabb tanulmányi eredményekhez, a fejlődés megrekedéséhez, a korai iskolaelhagyáshoz. Az iskolák orvosolni próbálják ezeket a hátrányokat, felzárkóztatni kívánják a „hátrányokkal küzdő” gyerekeket, azonban megállapítják, hogy erre nincsen elegendő erőforrásuk, így ez a törekvés jelenti számukra a legnagyobb - és egyben megoldatlan - kihívást az oktatás területén.

A második értelmezési elmélet a szegregációmodell. Az esélyegyenlőtlenségek kialakulásának magyarázatában ez a modell nem tér el a deficitmodelltől - tehát a gyerekek a családjukból az iskolába hátrányokkal érkeznek -, azonban ez az értelmezés a diákok közötti különbségek mélyüléséért az iskolarendszert teszi felelőssé. Az elmélet azt mondja ki, hogy az iskolákban szelekció történik, különválasztják a jó és a hátrányos helyzetü családok gyerekeit. Ennek hatására a hátrányos helyzetű gyerekek homogén csoportokban tanulnak, tehát a diákok nem tapasztalnak pozitív példát, nincs olyan tanuló, aki ösztönzőleg hatna rájuk, csak egymás viselkedési mintáit tapasztalják meg. Ebben az értelmezésben az esélyegyenlőtlenségeket a gyerekek egymástól való elválasztása eredményezi.

A harmadik értelmezési modell a látensdiszkrimináció-modell, amely a deficit- és szegregációmodell kritikájaként jött létre. Ezekkel ellentétben a látensdiszkrimináció-modell azt mondja, hogy a gyerekek nem érkeznek hátrányokkal az iskolába, hanem az iskolák működésének rendszere generálja ezeket a különbségeket. A közoktatási intézmények a jó (vagy jobb) szociális háttérrel rendelkező gyerekek tudásához, kommunikációs készségéhez, viselkedési formáihoz és normáihoz igazodnak. Azok a gyerekek, akik ettől eltérnek, hátrányokat élnek meg, mivel az iskolák nem illeszkednek hozzájuk. A látensdiszkrimináció-modell azt mondja, hogy a szegényebb (vagy szociálisan hátrányos helyzetü) gyermekek nem tudnak kevesebbet a világról, hanem más tudásalappal rendelkeznek, mint a tehetősebb családok gyermekei. Nem mondhatjuk, hogy rosszabb a kommunikációs készségük, csak az iskolák által preferált verbális kommunikációjuk gyengébb. Nem ítélhetők el az általuk mutatott viselkedési formák és az általuk birtokolt normák, csak ezekkel a közoktatási intézmények nem tudnak mit kezdeni.

Az esélyegyenlőtlenségek csökkentése nehéz feladat, hisz a deficit- és szegregációmodell mélyen gyökerezik a pedagógiai gondolkodásban. Az tapasztalható, hogy akik az esélyegyenlőtlenségek csökkentéséért munkálkodnak, sok esetben ők is a deficit- vagy 
szegregációmodell szerinti megközelítésben hisznek. Azonban az ország és az egyén szempontjából is az esélyegyenlőtlenségek csökkentéséért tenni kell, amihez sok tanulásra és pedagógiai kultúraváltásra lenne szükség (Nahalka, 2016). Kulcsfontosságú szerepe van ebben a pedagógusképzésnek. Olyan hatékony eljárásokkal, módszerekkel kell megismertetni a pedagógusokat, amelyek a látensdiszkrimináció-modell szerinti különbségek felhasználásával segítenek megteremteni a gyermekek méltányos együttnevelésének kereteit. Ezáltal minden gyerek számára elérhetővé válna a társadalmi mobilitás lehetősége. Ilyen eljárásnak mondható a státuszkezelés.

\section{Státuszkezelés}

A státuszkezelés olyan pedagógiai eljárás vagy beavatkozás, amelynek célja a tanulók közötti egyenlő vagy közel egyenlő interakció kialakítása, amely a feladatokhoz való egyenlő hozzá-

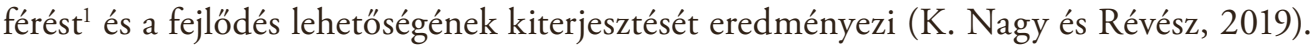
Az osztálytermi státusz egy olyan hierarchikus skálán elfoglalt pozíció, amelyet a diákok saját maguk hoznak létre egymásról alkotott vélekedésük, elvárásaik alapján (Cohan és Lotan, 2014, 1995; K. Nagy, 2015). A közösség minden tagja érzi, hogy kedvezőbb a magasabb pozíciót birtokolni, mint az alacsony státuszt. Az alacsony státuszú tanulókat a visszahúzódó viselkedés, a kevés kommunikáció, a feladattól való elzárkózás vagy kirekesztés jellemzi. Társaik nem tekintik őket kompetensnek a feladatmegoldás során, véleményüket nem kérik, nem veszik figyelembe és/vagy nem fogadják el. Ezzel szemben a magas státuszú diákokat társaik elismerik, kompetensnek tekintik, véleményükre odafigyelnek. Ebből következően a magas státuszt birtokló tanulók sokat beszélnek, domináns viselkedést mutatnak (Bianchini, 1998; Chizhik és Goodman, 2009; Cohan és Lotan, 1995; K. Nagy, 2015; K. Nagy és Révész, 2019).

A státuszkezelés lényege, hogy a pedagógus módosítja az osztályban kialakult státuszhelyzetet azáltal, hogy megváltoztatja „a tanulóknak mind önmagukkal, mind egymással szemben a kompetencia tekintetében támasztott elvárásait” (K. Nagy és Révész, 2019, 25. o.). A státuszkiegyenlítésre két lehetőség különíthető el: egyfelől a különböző képességek bevezetése, szem előtt tartása, másfelől az alacsony státuszú tanulók „kompetenciával való felruházása” (K. Nagy és Révész, 2019, 25. o.). Az első megoldási lehetőséghez az szükséges, hogy a pedagógus szemlélete túlmutasson az alapkompetenciákon (írás - olvasás - számolás),

\footnotetext{
$1 \mathrm{Az}$ „egyenlő hozzáférés” alatt fizikai és intellektuális hozzáférést egyaránt kell érteni. A fizikai hozzáférés azt jelenti, hogy a csoportmunka során a feladat megközelíthető minden tanuló számára, a társak nem rekesztenek ki senkit. Az intellektuális hozzáférhetőség a nyelvi akadályok leküzdését jelenti. Az a tanuló, aki a verbális kommunikáció tekintetében nehézségekkel küzd, több, részletesebb magyarázathoz kell hogy jusson, hogy számára is érthetővé váljon a tananyag, a feladat.
} 
ne ezek alapján hozzon ítéletet a tanulókról (okosok-buták), és ne is gondolkozzon ilyen különbségtételben. A többféle képesség bevezetésével a pedagógus lehetőséget kínál diákjainak, hogy megmutassák sajátos ügyességüket, erősségüket. Amennyiben az alacsony státuszú diák megmutathatja erősségeit, megismertetheti társaival, hogy miben jó, és a pedagógus ezt nyilvános elismeréssel fogadja, úgy az adott diákkal szembeni kompetenciaelvárás elkezd módosulni. A másik státuszkezelési lehetőség - miszerint az alacsony státuszú diákokat kompetenciával látja el a pedagógus - kulcsa szintén a többféle képesség elfogadásának szemlélete. A pedagógus elismerése ekkor ráirányul az alacsony státuszú tanulókra, és felhívja a figyelmet arra, hogy az adott diák fontos tagja a csoportjának (Cohan és Lotan, 2014; K. Nagy, 2015; K. Nagy és Révész, 2019).

\section{Státuszkezelés a gyakorlatban}

A Komplex Instrukciós Program (KIP) a tanulók között kialakult státuszkülönbségek kompenzálására irányuló tanulási-tanítási stratégia. A KIP Complex Instruction néven Amerikában a kaliforniai Stanford Egyetemen Cohen és Lotan professzorok vezetésével került kidolgozásra. K. Nagy Emese volt az, aki a magyarországi oktatási helyzethez adaptálta az eredetileg a bevándorlók iskolai lemaradására kifejlesztett, projektmódszerként alkalmazott stratégiát. A KIP-et elsődlegesen K. Nagy Emese KIP-könyv I-II. (2015) és Több mint csoportmunka (2012) című könyvei alapján mutatjuk be.

A KIP-módszer státuszkezelést segitö elemei: a nyitott végü, innovatív gondolkodást igénylö csoportfeladatok és az órán alkalmazott szerepek. A csoportfeladatok nyitottvégüsége azt jelenti, hogy több megoldással és megoldási lehetőséggel rendelkeznek, illetve hogy az alapkészségeken kívül többféle készséget, képességet, intelligenciatípust ${ }^{2}$ mozgósítanak. A KIP-es órákon a diákok 4-5 fös csoportokban dolgoznak, együttműködnek, de meghatározott szerepek ${ }^{3}$ szerint tevékenykednek, ezeknek a feladatköreit el kell látniuk. A szerepek közül a Kistanárt (középiskolában a megnevezése Irányító) szükséges kiemelni, amelynek státusznövelő hatása van (K. Nagy, 2015). A Kistanár feladata, hogy mindenkinek elmagyarázza az elkészítendő feladatot. Kiosztja a munkát, és megszervezi a munkavégzést. Szükség esetén ő az, aki a pedagógustól segítséget kér. A szerepkör domináns jelenlétet igényel az adott tanulótól. A Kistanár szerep nagyban hozzájárul az alacsony státuszú tanuló kompetencianöveléséhez azáltal, hogy a szerep betöltésével ráirányul a figyelem, irányító, döntéshozó tevékenységet kell végeznie.

2 Gardneri intelligenciatípusok: logikai-matematikai, nyelvi, zenei, térbeli, testi-kinesztéziás, interperszonális és intraperszonális (Gardner, 2011; Gardner és Hatch, 1989).

3 Alkalmazott szerepek: Kistanár, Beszámoló, Írnok, Rend-, Csend-, Idő- és Eszközfelelős. 
A szerepek a csoporton belül óráról órára rotálódnak. A pedagógus addig nem változtatja a csoport összetételét, amíg minden diák legalább egyszer be nem töltötte a Kistanár szerepet. Ez azt eredményezi, hogy az alacsony státuszú diákok is belekerülnek egy olyan helyzetbe, ahol domináns viselkedést várnak el tőlük, ezzel tudatosan megteremtve a lehetőséget, hogy rájuk terelődjön a figyelem (K. Nagy, 2015, 2014, 2012).

A KIP-es órák alkalmával a pedagógus irányító szerepét átruházza a Kistanárokra, és a szervező, moderáló szerepkört tölti be. Azáltal, hogy visszahúzódik és átadja a magyarázó, fegyelmező, döntéshozó tevékenységét, növeli a csoportokon belüli együttműködést és egymásrautaltságot. A diákok kommunikációja minden esetben egymás felé irányul, ami interperszonális kapcsolatuk erősödéséhez, fejlődéséhez vezet. (K. Nagy, 2015) A pedagógus visszahúzódó viselkedése nem kivonulást vagy koncentrációvesztést jelent. Figyeli a diákok tevékenységét olyan szituációk, esetek után kutatva, amikor egy alacsony státuszú diák olyat tesz vagy mond, amelynek kiemelésével pozitívan befolyásolhatja a társai vele szembeni megítélését.

\section{A kutatás bemutatása}

Kutatásunk célja a státuszkezelés megismertetésére irányuló továbbképzés eredményesebbé tétele, tehát hogy a státuszkezelés minél több pedagógus osztálytermi tevékenységébe beépüljön. Ehhez szükséges feltárni azokat a tényezőket, amelyek a pedagógusokat befolyásolják a státuszkezelés jövőbeli alkalmazásával kapcsolatban. A következő kérdésekre keressük a választ: Mi alapján fogadják el a pedagógusok a státuszkezelést? Milyen tényezök befolyásolják öket a státuszkezelés jövöbeli alkalmazásáról való döntésükben?

Amennyiben ezeket a tényezőket megismertük, felismertük, úgy a képzőknek lehetőségük lesz ezeket a tényezőket a továbbképzések alkalmával pozitívan befolyásolni. Feltevésünk, ha ezeket a tényezőket pozitív hatás éri, ezek megerősítése kerül a fókuszba, úgy hatékonyabbá válik a pedagógusok fejlesztése, fejlődése, nagyobb valószínűséggel épül be a státuszkezelés a pedagógiai tevékenységbe.

\section{A kutatás folyamatának ismertetése}

Kutatásunk tárgya a pedagógusok döntése, amelyet a státuszkezelés alkalmazásával kapcsolatban hoznak meg. Ezt nem közvetlen, hanem közvetett módon kívánjuk felmérni, méghozzá a státuszkezelést megismertető szakértők, képzők tapasztalatainak feltárásával. Annak indoka, hogy miért nem kérdezzük meg közvetlenül a pedagógusokat a státuszkezelés elfogadásáról az, hogy kutatói tapasztalatok azt támasztják alá, hogy a válaszadók ilyen esetben törekednének a „jó válasz” megadására, így a felmérés eredményei torzulnának. 
Szakmai konzultációt követően döntöttünk a képzők felmérése mellett, így remélve azt, hogy a legőszintébb válaszokat kapjuk a vizsgálat során.

A képzői tapasztalatok tehát a pedagógusok fejlesztéséről szólnak. A tapasztalatok elemzéséhez segítségül hívunk egy széles körben ismert és alkalmazott elfogadásmodellt (Technology Acceptance Modell - TAM). A TAM-modellek 1986 óta az elfogadással kapcsolatos kutatások ${ }^{4}$ elméleti alapját képezik (Lee, Kozar és Larsen, 2003; Davis, 1986).

Az ezekben a modellekben megjelenő tényezők ${ }^{5}$ közül kijelöljük azokat, amelyek a leginkább adaptívnak tekinthetők a kutatásunk számára ${ }^{6}$. Az így kapott adaptív tényezőkből egy kategóriarendszert hozunk létre, amely a képzők válaszainak elemzésében nyújt segítséget. A kvalitatív módon elemzett válaszok segítenek kijelölni azokat a tényezőket, amelyek a képzői tapasztalatok alapján a leginkább befolyásolják a pedagógusok státuszkezeléssel kapcsolatos döntését. Emellett idézeteket közlünk a válaszokból, amelyeket tanulságos áttanulmányozni a státuszkezelés megismertetésével kapcsolatban a fellépő nehézségek megismerése szempontjából.

\section{Adatgyüjtés}

Vizsgálatunk 2018. március-áprilisban zajlott. Online kérdőívet használtunk az adatgyüjtéshez.

A kérdőívben szereplő nyitott végü kérdések a következők voltak:

- Tapasztalatai szerint hogyan lehet a státuszkezelést eredményesen MEGISMERTETNI a pedagógusokkal?

- Tapasztalatai szerint hogyan lehet a státuszkezelést eredményesen ELFOGADTATNI a pedagógusokkal?

- Utókövetések során milyen vélemények érkeznek a pedagógusok felöl a státuszkezelés alkalmazásával kapcsolatban?

\section{Minta}

Vizsgálatunkban 15 képzőt kérdeztünk meg a pedagógusok státuszkezelésre való felkészítésével, fejlesztésével kapcsolatban szerzett tapasztalataikról. A mintavétel tudatosan zajlott. Azokat a képzőket vontuk bele a vizsgálatba, akik a legtöbb pedagógus-továbbképzést tartották a státuszkezelés megismertetéséről. Ök 8-10 éve gyakorlatban alkalmazzák

4 Monda és Ugray (2014); Nyírő (2011); Venkatesh és Bala (2008); Venkatesh és Davis (2000); Davis (1989); Davis, Bagozzi és Warshaw (1989).

5 A modellekben megjelenő tényezők teljes listáját mellékletben (Melléklet 1) közöljük.

6 A TAM elsősorban technológiai elfogadást vizsgál. A tényezők ebből következően technológiai fogalmak. A kutatásunk számára ezen tényezők közül azok adaptációjára van szükség, amelyek a leginkább illeszkednek a pedagógiai környezethez. 
a módszert közoktatási intézményekben, és pedagógus-továbbképzéseken mutatják be a KIP-et és a státuszkezelést. Személyenként átlagosan 30-50 pedagógus-továbbképzést tartottak.

\section{Adatelemzés}

A beérkezett képzői válaszokat kvalitatív tartalomelemzési technikával elemezzük. Deduktív tartalomelemzési módot alkalmazunk, tehát előre elkészített kategóriarendszert hozunk létre, és ennek segítségével történik a válaszok kódolása. Fenntartjuk annak lehetőségét, hogy amennyiben a válaszok elemzése során olyan többletinformációkat kapunk, amelyek túlmutatnak az általunk alkotott kategóriarendszeren, de pozitív irányba mozdítanák kutatásunk eredményességét, úgy induktív módon a válaszok alapján módosítjuk a kódolási rendszert, így minimalizálva az adatvesztést.

A válaszok kódolása során több esetben tapasztaltuk, hogy az általunk felállított kategóriarendszerben szereplő keresőszavak helyett a képzők körülírással utaltak ugyanarra a tényezőre. Ezeket az eseteket is figyelembe vettük, és a kategóriarendszertől eltávolodva az adott tényezőre utaló körülírásokat kódoltuk.

\section{A kategóriarendszer}

Ahogy a fentiekben már említésre került, a TAM-modellek tényezői közül kijelölésre került, a pedagógiai kutatáshoz adaptálható tényezők kerülnek a kategóriarendszerbe. Mindegyik tényező mellé ellentét- és szinonimapárokat rendelünk, amelyek a képzők válaszainak keresőszavaiként funkcionálnak. A keresőszavakat a Magyar szinonimaszótár (O. Nagy és Ruzsiczky, 1983), a Magyar szókincstár (Kiss, 2011), illetve online szinonimaszótár és ellentétszótár felhasználásával jelöljük ki. Tehát az általunk használt kategóriarendszer a következő: 


\begin{tabular}{|c|c|}
\hline $\begin{array}{l}\text { Észlelt hasznosság }{ }^{7} \\
\text { (hasznos) }\end{array}$ & $\begin{array}{l}\text { megfelelö, hasznot hajtó, előnyös, hasznavehető, hasznosítható, } \\
\text { felhasználható, alkalmazható, praktikus, célszerű, használható, } \\
\text { igénybe vehető, eredményes, termékeny } \\
\text { haszontalan, hasznavehetetlen, használhatatlan, alkalmatlan, } \\
\text { eredménytelen, sikertelen }\end{array}$ \\
\hline $\begin{array}{l}\text { Használat észlelt egyszerűsége } \\
\text { (egyszerű, egyszerűen használható) }\end{array}$ & $\begin{array}{l}\text { átlátható, áttekinthető, könnyű, elemi, érthető, világos } \\
\text { bonyodalmas, bonyolult, komplex, komplikált, sokrétű, } \\
\text { összetett }\end{array}$ \\
\hline Attitűd & $\begin{array}{l}\text { modor, szokás, viselkedés, magatartás, habitus, magaviselet, } \\
\text { fellépés, kiállás, viselkedésmód, hozzáállás, viszonyulás }\end{array}$ \\
\hline Munkarelevancia & $\begin{array}{l}\text { fontos, nélkülözhetetlen, alapvető, lényeges, elemi, lényegbeli, } \\
\text { központi, középponti, esszenciális }\end{array}$ \\
\hline (pedagógiai tevékenységéhez releváns) & $\begin{array}{l}\text { elengedhetetlen, jelentős, jelentőségteljes, meghatározó, } \\
\text { létfontosságú, kulcsfontosságú, kardinális, sokat számító, } \\
\text { hangsúlyos, kulcsponti, sarkalatos, lényegi, súlyponti, mérv- } \\
\text { adó, pótolhatatlan, fö, kötődő, kapcsolatban álló, kapcsolatos, } \\
\text { idevágó } \\
\text { irreleváns, mellékes, lényegtelen }\end{array}$ \\
\hline $\begin{array}{l}\text { Személyes fejlődőkészség } \\
\text { (fejlődés, fejlődő) }\end{array}$ & $\begin{array}{l}\text { növekedés, gyarapodás, előrelépés, haladás, változás, emel- } \\
\text { kedés, modernizáció, innováció, előrehaladás, föllendülés, } \\
\text { virágzás, prosperálás, gyarapodó, fokozódó, gyümölcsöző } \\
\text { regresszív, visszafejlődő }\end{array}$ \\
\hline $\begin{array}{l}\text { Önhatékonyság }{ }^{8} \\
\text { (hatékony) }\end{array}$ & $\begin{array}{l}\text { hatásos, eredményes, termékeny, célravezető, hathatós, } \\
\text { produktív, effektív } \\
\text { hatástalan, eredménytelen, sikertelen, kárba veszett, } \\
\text { haszontalan }\end{array}$ \\
\hline $\begin{array}{l}\text { Észlelt élvezhetőség } \\
\text { (élvezetes) }\end{array}$ & $\begin{array}{l}\text { szórakoztató, jóleső, mulattató, élvezhető, kellemes, örömteli } \\
\text { egyhangú, egysíkú, eseménytelen, lapos, monoton, sótlan, } \\
\text { színtelen, szürke, unalmas, változatosság nélküli }\end{array}$ \\
\hline $\begin{array}{l}\text { Előzetes tapasztalatok } \\
\text { (tapasztalat) }\end{array}$ & $\begin{array}{l}\text { hozzáértés, tudás, tájékozottság, ismeret, képzettség, jártasság, } \\
\text { szakértelem, szaktudás, szakszerűség, szakismeret, rutin, } \\
\text { kompetencia, készség }\end{array}$ \\
\hline
\end{tabular}

\section{1. táblázat. A kategóriarendszer}

A kategóriarendszer (1. táblázat) a következőképpen értelmezhető: a bal oldali oszlop a tényezőket tartalmazza, alattuk zárójelben olyan kifejezések olvashatók, amelyek a jobb oldali oszlopban található szinonima- és ellentétpárokat adják meg.

7 Az eljárásra, vagyis a státuszkezelésre vonatkoztatva.

8 A személyre, vagyis a pedagógusra vonatkoztatva. 


\section{Az eredmények ismertetése}

A tartalomelemzés során számláltuk, hogy az egyes válaszadók a válaszaikban említik-e a keresőszavak valamelyikét. Minden egyes keresőszó egy tényező manifesztációja. Alapelvként fogalmaztuk meg, hogy ha a válaszadó az adott tényezőhöz tartozó keresőszót többször említi a válaszában, akkor azt a tényezőt csak egyszer vesszük számításba az adott válaszadó vonatkozásában. A válaszok elemzésének eredményét a következő diagram mutatja:

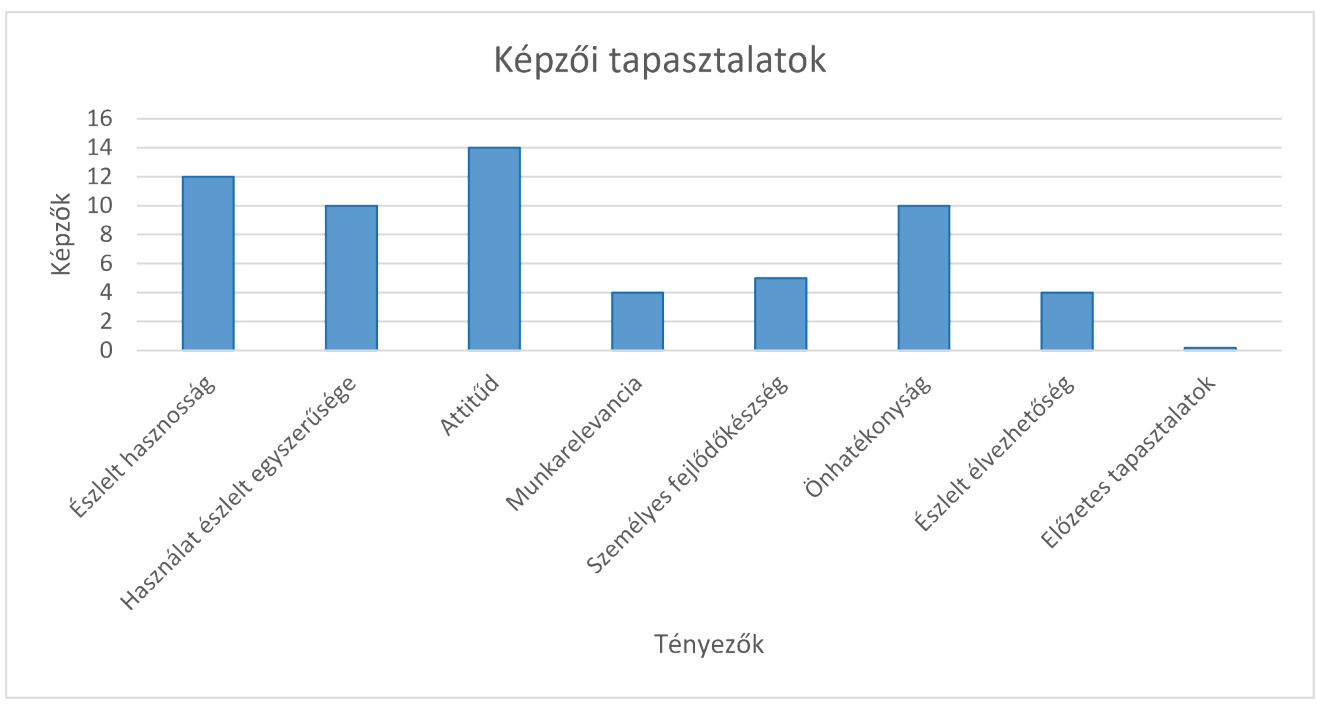

1. ábra. Képzöi válaszok összegzése

A képzői válaszokban (1. ábra) az Attitűdöt mint tényezőt említették a legtöbben: 15 képző közül 14 fogalmazott meg erre vonatkozóan tapasztalatot. 12 képző említette, hogy fontos a pedagógusok státuszkezelésre való felkészítésében a státuszkezelés Hasznosságának tisztázása, kiemelése. 10 képző fogalmazott meg véleményt arról, hogy a státuszkezelés alkalmazásának nehézsége erős befolyást gyakorol az általuk mentorált pedagógusok vélekedésében, és - feltételezhetően ezzel összefüggésben - szintén 10 képző említette, hogy a pedagógusoknak a státuszkezelés alkalmazásával kapcsolatos döntését döntően befolyásolja az, hogy mennyire illeszkedik saját kompetenciájuk a státuszkezelés alkalmazásához. Összegezve a megjelölt 8 tényező közül a következő 4 került kijelölésre a képzői válaszok alapján: Észlelt hasznosság, Használat észlelt egyszerüsége, Attitüd és Önhatékonyság.

Az előzőekben említésre került, hogy nem minden esetben volt célszerü ragaszkodnunk a felállított kategóriarendszerünk keresőszavaihoz. Induktív módon a kódoláson változtattunk. Erre azért volt szükség, mert a képzői válaszok elemzésekor megfigyeltük, hogy 15 
képzőből 11 említést tett bizonyos negatív tényezőkről, amelyek a pedagógusokat befolyásolják a státuszkezelés jövőbeli alkalmazásával kapcsolatban. Ezek elsődlegesen az idő- és eszközhiányra, illetve a vezetői támogatás hiányára vonatkoznak. Szükséges megemlíteni, hogy a státuszkezelés alkalmazásának nem feltétele az idő, eszköz vagy szakmai támogatás megléte. A státuszkezelés egy szemléletbeli elhivatottságot ${ }^{9}$ igényel a pedagógustól, amelyhez nincs szükség külső segítségre. Mivel azonban a képzők jelentős része megélt ezzel kapcsolatos tapasztalatokat a pedagógusokkal való fejlesztőmunka folyamán, ezért ezt a tényezőt sem hagyhatjuk figyelmen kívül. Ebből kiindulva a megjelölt 4 tényező mellé beemelünk még egyet, amelyet összefoglalóan Akadályokként nevezünk el.

Az adatelemzés során több esetben megtörtént, hogy a kategóriarendszerünk keresőszavait nem találtuk a képzői válaszokban, azonban egy adott tényezőre utaló körülírás jelent meg. Ezeket a válaszokat is figyelembe vettük, és az eredményeket összesítő diagramban ezek is szerepelnek. A körülírásokat idézetek formájában közöljük, ezek nemcsak az adott tényező szempontjából érdekesek, hanem a képzői tapasztalatok mélyebb megismerése szempontjából is tanulságosak. Az idézeteket az adott tényezőhöz besorolva közöljük.

Észlelt hasznosság:

- „Pozitivan hat rájuk [a pedagógusokra], ha öszintén elmondom a tapasztalataimat."

(egy képző válasza)

- „Gyakorlati példák és gyakorlati feladatok segitségével mutatom be a státuszkezelést."

- „[...] arról beszélt (a pedagógus a képzőnek), hogy a gyerekek kedvesebbek egymással, amióta a státuszkezelést próbálgatja."

- „Pozitiv elmozdulást tapasztaltak a kollégák az alacsony státuszú diákjaik munkavégzésében, tanórai viselkedésében."

- Az egyik képző idézte fel az utókövetés alkalmával tapasztalt pedagógusi élménybászámolót: „Ragyogó Beszámoló lett az addig teljesen csendes diákból. [...] A legkevésbé sikeres diákból remek Kistanár lett, mert kiderült róla, hogy jó szervezö."

- Egy másik képző idézi az egyik mentorált pedagógusának szavait: „Könnyebb lett a gyerekeket tanitani.”

9 Itt a Bevezetésben említésre került látensdiszkrimináció-modell szerint magyarázott elmélet iránti elhivatottságot értjük. Vagyis hogy az esélyegyenlötlenségeket az iskolák generálják, és nem a gyerekek hozzák magukkal, nincs butább gyerek, csak más tudásalappal rendelkező tanuló. 
Használat észlelt

egyszerüsége:
- „Kezdetben nehézséget jelent a kollégák számára a megosztott figyelem, a diákok tevékenységének átlátása. Sok esetben fontos információkról maradnak le. Ez elkedvetlenitheti öket a státuszkezelés alkalmazásában."

- „A pedagógusoknak nehéz a státuszkezelés, mert nehéz számukra kilépni a hagyományos pedagógusszerepböl."

Attitüd:

Önhatékonyság:
- „[a továbbképzésen részt vett pedagógusok] nem hisznek a státuszkezelés erejében."

- "Fontos, hogy azonosulni tudjanak vele [a státuszkezeléssel].”

- „A képzések alkalmával kialakitott jó hangulat pozitivan hat a pedagógusok megitélésére."

- "Pozitivan állnak hozzá [a státuszkezeléshez].”

- "A fejlödés lehetösége pozitivan hat rájuk [a pedagógusokra]."

- "Minél több az interaktivitás, annál érdeklödöbbek a kollégák."

- "A pedagógusok hozzáállásában nagyon fontos a képzö személyisége."

- "Biztatni kell őket [a pedagógusokat].”

- "Nehéz megváltoztatni az elözetes negativ hozzáállást.”

- „A feladatok közös megszerkesztésével fejlödik az önbizalmuk.”

- „Amikor megbeszéljük, hogyan tudják bevezetni a saját iskolájukba [a státuszkezelést], akkor lelkesebbé válnak a kollégák.”

- "A pedagógusok arról számoltak be, hogy kreativabbá váltak a nyitott végü feladatok kitalálása folyamán."

- „Kezdetben nem értette [az adott pedagógus], hogy miért nem tudja belevonni mindegyik tanulót a csoportmunkába, de a státuszkezelés alkalmazásával ez sikerült neki.”

- „Egyik alkalommal [utókövetés alkalmával] azt mondták a kollégák, hogy a videófelvételek megnézésekor azt érezték, ezt ök is meg tudják csinálni."

- "Ahol a pedagógus személyisége alapveto”en empatikus, ott gyorsabban és könnyebben megy a tudatos státuszkezelés alkalmazása." 


\section{Az eredmények összegzése}

A kutatásunk során feltárt eredmények összegzését tesszük meg. A feltárt tényezőket a képzői válaszok alapján rövid definícióval láttuk el. Ezek a következők:

- Észlelt hasznosság: A pedagógusoknak azzal kapcsolatos gondolata, vélekedése, hogy a státuszkezelés milyen mértékben hoz eredményt az általuk tanított diákok viselkedésében, tanulmányi előmenetelében, milyen előnyökkel jár az alkalmazása.

- Használat észlelt egyszerüsége: A pedagógusok azzal kapcsolatos vélekedése, ítélete, hogy a státuszkezelés mennyire könnyen vagy nehezen kivitelezhető az osztálytermi munkájuk során.

- Attitüd: A pedagógusok státuszkezeléssel kapcsolatos hozzáállása, viszonyulása, pozitív vagy negatív megítélése.

- Önhatékonyság: A pedagógusok azzal kapcsolatos gondolata, vélekedése, hogy mennyire képesek eredményesen, hatékonyan kezelni a diákjaik között kialakult státuszkülönbségeket.

- Akadályok: A pedagógusok által megélt, vélt negatív benyomás/inger, amely a státuszkezelés alkalmazásának lehetőségét csökkenti.

\section{Következtetések}

Kutatásunk során a státuszkezelés megismertetését végző képzők tapasztalatainak feltárása történt meg a pedagógusok fejlesztésével kapcsolatban. Közvetett módon vizsgáltuk a pedagógusok döntését befolyásoló tényezőket, amely döntés a státuszkezelés alkalmazásával kapcsolatban értendő. Célunk ezzel a kutatással az volt, hogy amennyiben feltárjuk a befolyásoló tényezőket, egy továbbképzés alkalmával az ezekre a tényezőkre való megerősítéssel eredményesebbé tehető a státuszkezelés ismereteinek az elsajátítása.

A nyitott végű kérdésekre adott képzői válaszok elemzését követően a következő tényezőket tártuk fel: Észlelt hasznosság, Használat észlelt egyszerüsége, Attitüd és Önhatékonyság. Ezek mellé beemelésre került az Akadályok tényező. Az Akadályok mint negatív, hátráltató tényező értelemszerűen nem jelenik meg a továbbképzés folyamán, ezekről a képzők az utókövetések alkalmával beérkező pedagógusi véleményekből értesülnek. A következő alfejezetekben a státuszkezelést megismertető továbbképzés egységeinek, részegységeinek bemutatását tesszük meg a K. Nagy Emese és T. Fehér Mária (2018) által kidolgozott Képzöi kézikönyv alapján. A következőkben a tényezőkre tett kijelentések a fentebb bemutatott vizsgálaton alapulnak. Emellett szóbeli konzultáció keretein belül 3 képző nyújtott segítséget a továbbképzés részegységei tényezőkre gyakorolt hatásának felderítésében. Az alfejezet felépítése a Képzői kézikönyvben megjelenő tematikai egységek szerkezetét követi. 


\section{Pedagógiai kultúraváltás}

A továbbképzés első részegysége során a képző az ismerkedés keretein belül a pedagógusok tapasztalatait hozza felszínre az iskolákban tapasztalt, tantermen belüli problémák, sikerek, sikertelenségek kimondatásával. Ennek célja a pedagógusok meglévő nézeteinek feltárása, és a szakmai diskurzussal a pedagógusok Attitüdjére kíván hatni.

Az ismerkedést követően elméleti rész következik, amely során a képző az osztálytermi méltányosság megteremtéséről, a státuszkezelés alkalmazásáról tart egy rövid előadást. A képzői segédanyag tanulmányozását követően megállapítható, hogy ez az egység a Hasznosság tényezőjét erősíti, mivel a képző által bemutatott ppt tudományos megalapozást nyújt a státuszkezelés jelentőségéről.

A következőkben a képző szimulált tanítási órát szervez a pedagógusok aktív részvételével. A szimulált óra alkalmával a képző a KIP-módszert alkalmazza. A szimulált óra alatt a pedagógusok diákként, a gyerekek szemszögéből tapasztalják meg a KIP-módszert, következésképpen a státuszkezelést. A szimulált óra tanulóként való átélése során a pedagógusok az eljárás Hasznosságát tapasztalhatják meg, illetve erősen hat az Attitüdjükre. Ebben a helyzetben a Használat egyszerűségének megtapasztalásáról még nem beszélhetünk, hisz ekkor a pedagógusok a státuszkezelést megélik, átélik és nem alkalmazzák.

Ebben a tematikai részegységben utolsó részként nevelési szituációs játékon vesznek részt a pedagógusok. Ilyen jellegű nevelési játék több esetben jelenik meg a továbbképzés folyamán. Ennek jelentősége, hogy a pedagógusok megtanulják, hogyan érzékenyítsék diákjaikat, hogyan vezessék rá őket a hatékony együttműködésre, csoportmunkára. A nevelési játékok diákként való megismerése, majd ezután a tapasztalatok megbeszélése szakmai diskurzus keretein belül erősíti a pedagógusok Attitüdjét a státuszkezelés jelentőségével kapcsolatban.

\section{Stratégia}

A második rész elsőként egy rövid előadással kezdődik, amely a heterogén osztály kezeléséről, fejlesztéséről szól. Ez gyökeresen nem tartozik a státuszkezelés megismertetéséhez, de a pedagógusok szemléletének formálásában jelentős szerepe van. A következő részegységben ismételten egy nevelési játék jelenik meg, amelynek jelentőségét fentebb említettem. A harmadik részegység ismételten frontális előadás, amely során oktatásszervezési módokat mutat be a képző.

A negyedik részegység a tanulói státuszkezelö óra (KIP) elemzése. A továbbképzésnek ez a részegysége rendkívül jelentős. Ekkor találkoznak a pedagógusok a státuszkezeléssel pedagógusként, tehát már nem mint tanulók élik át a státuszkezelést, hanem mint felhasználók tanulják meg ennek alkalmazási lehetőségeit. A KIP szerint szervezett órákon alkalmazott feladatok leírásának tanulmányozása, kötelező elemeinek azonosítása történik ebben a tematikus részegységben, amely a tényezők közül a Használat egyszerüségére hat. 
A következő részegységben az említett feladatok szerkesztése történik. Ekkor már a pedagógusok saját maguk próbálnak nyitott végű csoportfeladatokat és ezekhez illeszkedő egyéni feladatokat kitalálni. Az, hogy próbálgatják a tanult elveket betartani, minél kreatívabb, innovatívabb feladatokat hoznak létre a státuszkezelés segítésére, az Önhatékonyságukat erősíti.

Ezt követően ismételten érzékenyítő nevelési játékot mutat be a képző, majd „szükség szerint” újbóli szimulált órát vezet le. Ennek a szükségességéről a képzőnek a továbbképzés folyamán kell dönteni.

A következőkben ismételten feladatok szerkesztésének gyakorlására kéri a képző a pedagógusokat, akikből kiscsoportok szerveződnek, és egymást segítve, együtt ötletelve történik a fejlesztő tevékenység. Ez a részegység a pedagógusok Önhatékonyságára hat.

Ismételten egy nevelési játékot követően a pedagógusok a KIP bevezetésének lépéseivel ismerkednek meg. Hogyan lehet elkezdeni a tanultak alkalmazását az osztálytermi környezetben? Erre kapnak választ a pedagógusok, amely a Használat egyszerüségére hat.

A tematikai egység egy nevelési játék megismerésével, majd megvitatásával zárul.

\section{A pedagógiai kompetenciák fejlesztésének lebetöségei}

Ez a tematikai egység két részből áll. Az elsőben a képző a pozitív megerősítés jelentőségéről indít beszélgetést a pedagógusokkal. Attitüdjüket formálja és a státuszkezelés Hasznosságát erősíti az, hogy diskurzus alakul a státuszkezelésről a tanulók sikerességének, az alulmotiváltság megszüntetésének, a magatartások rendezésének tükrében. Ebben a részegységben a képző saját tapasztalatait és a státuszkezelést már alkalmazó kollégák véleményét is bemutatja a pedagógusoknak, amely során ismételten a Hasznosság és az Attitüd kerül megerősítésre.

Az egység zárásaként a következő e-learning tananyagegységre való felkészülés történik meg. Az ezzel kapcsolatos esetlegesen felmerülő kérdések megválaszolását teszi meg a képző, illetve az online önfejlesztéshez iránymutatást kínál a pedagógusoknak.

\section{E-learning tanfolyam}

Ez a tematikus egység szervesen már nem tartozik bele a továbbképzés menetébe, de a státuszkezelés elsajátításának eredményességében jelentős szerepet játszik, ezért elemzése releváns számunkra.

A továbbképzésen részt vett pedagógusok hozzáférést kapnak egy online felülethez, amely lehetőséget kínál a pedagógusoknak Önhatékonyságuk erősítésére. Ezen a felületen ötleteket találnak nyitott végű feladatokra, emellett a státuszkezelésről videókat nézhetnek meg, és megfigyelőlapok alkalmazásával tudatos önfejlesztés valósulhat meg, amelynek segítségével az Önhatékonyság mellett a Használat egyszerüsége tényező is erősödik. 


\section{Összegzés}

Kutatásunkban a státuszkezelés jövőbeli alkalmazását befolyásoló tényezőket tártuk fel a képzői tapasztalatok elemzésén keresztül. Online kérdőívben alkalmazott nyitott kérdésekkel kérdeztük meg a státuszkezelést megismertető legtapasztaltabb képzőket a pedagógusok státuszkezeléssel kapcsolatos fejlesztéséről. A kutatásunk során feltárt tényezők a következők: Észlelt hasznosság, Használat észlelt egyszerüsége, Attitüd és az Önhatékonyság, illetve beemelésre került az Akadályok tényező, amely a pedagógusokat negatívan befolyásoló körülmények összességét jelöli.

A befolyásoló tényezők feltárása akár előzménykutatásnak is tekinthető egy olyan vizsgálathoz, amely a tényezők egymásra gyakorolt hatását, domináns szerepét hivatott kideríteni. Jelen és a jövőben tervezett vizsgálatunk jelentőségét abban látjuk, hogy ezekkel a kutatásokkal a státuszkezelési ismeretek átadásának eredményessége fokozható azáltal, hogy feltárásra kerül, milyen tényezők megerősítésére érdemes figyelmet fordítani a továbbképzések alkalmával. Amennyiben a státuszkezelés beépül a gyakorló pedagógusok osztálytermi tevékenységébe, úgy a méltányosság megteremtődésének lehetősége is növekszik, amely elvezet az esélyegyenlőtlenségek csökkentéséhez.

\section{Felhasznált irodalom}

Biachini, J. A. (1998): From here to equity: The influence of status on student access to and understanding of science. Science Education. 5. 577-601.

https://doi.org/10.1002/(SICI)1098-237X(199909)83:5<577::AID-SCE5>3.0.CO;2-F

Chizhik, A. és Goodman, J. (2004): Lower-Status Participation and Influence: Task Structure Matters. Journal of Social Issues, 65. 365-381.

https://doi.org/10.1111/j.1540-4560.2009.01604.x

Cohen, E. G. (1982): Expectations states and interracial interaction in school settings. Annual Review of Sociology, 8. 209-235.

https://doi.org/10.1146/annurev.so.08.080182.001233

Cohen, E. G. és Lotan, R. A. (2014): Designing groupwork: Strategies for heterogeneous classrooms. Teacher College, Columbia University, New York - London.

Cohen, E. G. és Lotan R. A. (1995): Producing Equal-Status Interaction in the Heterogeneous Classroom. American Educational Research Journal, 32. 99-120. https://doi.org/10.3102/00028312032001099

Davis, F. D. (1989): Perceived usefullness, perceived ease of use, and user acceptance of information technology. MIS Quarterly, 13. No. 3. 319-340.

https://doi.org/10.2307/249008 
Davis, F. D. (1986): A technology acceptance model for empirically testing new end-user information systems: Theory and results. Cambridge, MA: Massachusetts Institute of Technology.

Davis F. D., Bagozzi, R. P. és Warshaw, P. R. (1989): User Acceptance of Computer Technology: A Comparison of Two Theoretical Models. Management Science. 35. No. 8. 982-1003. https://doi.org/10.1287/mnsc.35.8.982

Gardner, H. (2011): Frames of mind: The theory of multiple intelligencies. Basic Books, New York. (Original work published in 1983)

Gardner, H. és Hatch, T. (1989): Multiple Intelligences Go to School: Educational Implications of the Theory of Multiple Intelligences. American Educational Research Association, 18. 8. sz. 4-10. https://doi.org/10.2307/1176460

Keller Judit és Mártonfi György (2006): Oktatási egyenlőtlenségek és speciális igények. In: Halász Gábor és Lannert Judit (szerk., 2006): Jelentés a magyar közoktatásról 2006. Oktatáskutató és Fejlesztő Intézet, Budapest. 377-411.

Kiss Gábor (szerk., 2011): Magyar szókincstár. Tinta Könyvkiadó, Budapest.

K. Nagy Emese (2016): Milyen oktatást szeretnénk? Új Pedagógiai Szemle 66. 3-4. sz. $7-13$.

K. Nagy Emese (2015): KIP-könyv I-II. Miskolci Egyetemi Kiadó, Miskolc.

K. Nagy Emese (2014): A heterogén tanulói csoportok kezelése. In: Harmatiné Olajos Tímea, Pataky Nóra és K. Nagy Emese (szerk., 2014): A kétszeresen kivételes tanulók tehetséggondozása. Magyar Tehetségsegítő Szervezetek Szövetsége, Budapest. 123-179.

K. Nagy Emese (2012): Több mint csoportmunka. Nemzeti Tankönyvkiadó, Budapest.

K. Nagy Emese és Révész László (2019): Differenciált Fejlesztés Heterogén Tanulócsoportokban (DFHT) metódus mint a Komplex Alapprogram tanitási-tanulási stratégiája, fókuszban a tanulók státuszkezelése, Líceum Kiadó, Eger.

K. Nagy Emese és T. Fehér Mária (szerk., 2018): Differenciált Fejlesztés Heterogén Tanulócsoportban tanulási-tanitási stratégia, Líceum Kiadó, Eger.

Monda Eszter és Ugray Zsolt (2014): Az IKT-eszközökkel kapcsolatos preferenciák és használatuk előrejelzése. Vezetéstudomány. 45. 5. 21-38.

https://doi.org/10.14267/VEZTUD.2014.05.03

Nahalka István (szerk., 2017): Van kiút az oktatási katasztrófából. ROMI-SULI Könyvkiadó, Mogyoród.

Nahalka István (2016): Az esélyegyenlőség és a komprehenzivitás lehetősége és ellehetetlenülése. Új Pedagógiai Szemle, 66. 7-8. sz. 34-39.

Nyírő Nóra (2011): Médiatechnológiai innovációk elfogadása és terjedése. PhD-értekezés. Budapesti Corvinus Egyetem, Gazdálkodástani Doktori Iskola. 
Lee, Y., Kozar, K. A. és Larsen, K. R. T. (2003): The Technology Acceptance Model: Past, Present and Future. Communications of the Association for Information Systems. 12. No. 1. 752-780. https://doi.org/10.17705/1CAIS.01250

O. Nagy Gábor és Ruzsiczky Éva (szerk., 1983): Magyar szinonimaszótár. Akadémiai Kiadó, Budapest.

Venkatesh, V. és Bala, H. (2008): Technology Acceptance Model 3 and a Research Agenda on Interventions. Decision Sciences. 39. No. 2. 273-315. https://doi.org/10.1111/j.1540-5915.2008.00192.x

Venkatesh, V. és Davis, F. D. (2000): A Theoretical Extension of the Technology Acceptance Model: Four Longitudinal Field Studies. Management Science. 46. No. 2. 186-204. https://doi.org/10.1287/mnsc.46.2.186.11926

\section{Melléklet 1}

A TAM-modellekben megjelenő tényezők listája (Lee, Kozar és Larsen, 2003)

- Perceived Usefulness $\square$ Social Presence

- Perceived Ease of Use $\square$ Subjective Norms/ Social Influence

- Voluntariness $\square$ Visibility

- Relative Advantage $\square$ Job Relevance

- Compatibility $\quad \square$ Computer Attitude

- Complexity $\square$ Accessibility

- Observatibility $\square$ Result Demonstratibility

- Trialability $\square$ Management Support $\square$ Image $\square$ Computer Anxiety

- Self efficacy $\square$ Perceived Enjoyment

- End User Support $\quad \square$ System (Output or Information)

- Objective Usability $\square$ Quality

- Personal Innovativeness $\square$ Facilitating Conditions

- Computer Playfulness $\quad \square$ Prior Experience 